\section{Risk of systemic lupus erythematosus in patients with idiopathic thrombocytopenic purpura: a need for a more accurate control group?}

We read with great interest the recent paper by Zhu et al ${ }^{1}$ which studied the risk of developing systemic lupus erythematosus (SLE) in a population of patients with idiopathic thrombocytopenic purpura (ITP).

In their paper, Zhu et al performed a population-based retrospective cohort study in which they analysed the risk of SLE in a cohort of patients newly diagnosed with ITP between 2000 and 2013. Controls were selected at a 1:2 ratio through propensity score matching using the greedy algorithm. Zhu et al found an incidence rate of 62.0 per 100000 person-months $(95 \% \mathrm{CI}$ 44.3 to 86.8$)$ in the ITP group and of 2.10 per 100000 personmonths (95\% CI 1.44 to 3.06 ) in the non-ITP group, with an average follow-up time of 80 months. The adjusted HR of incidental SLE in the ITP group was 25.1 (95\% CI 13.7 to 46.0 ). Given that ITP is an immune-mediated disease, a control group consisting in patients with other autoimmune diseases (autoimmune haemolytic anaemia, Evans syndrome, thyroiditis...) might have been more accurate in order to compare the risk of developing SLE with other autoimmune diseases instead of using a standard control group, which could have artificially overestimated the risk of SLE.

Philippe Mertz $\odot$, Laurent Arnaud $\odot$
Centre National de Référence des Maladies Systémiques et Autoimmunes Rares Est Sud-Ouest (RESO), Department of Rheumatology, Strasbourg, France

Correspondence to Dr Philippe Mertz, Rheumatology Department, $\mathrm{CHU}$ Hautepierre, Strasbourg 67000, France; philippe.mertz@chru-strasbourg.fr

Contributors All authors contributed equally to the presented work.

Funding The authors have not declared a specific grant for this research from any funding agency in the public, commercial or not-for-profit sectors.

Competing interests None declared.

Patient and public involvement Patients and/or the public were not involved in the design, or conduct, or reporting, or dissemination plans of this research.

Patient consent for publication Not required.

Provenance and peer review Not commissioned; internally peer reviewed.

(c) Author(s) (or their employer(s)) 2020. No commercial re-use. See rights and permissions. Published by BMJ.

\section{Check for updates}

To cite Mertz P, Arnaud L. Ann Rheum Dis Epub ahead of print: [please include Day Month Year]. doi:10.1136/annrheumdis-2020-217651

Received 17 April 2020

Accepted 18 April 2020

Ann Rheum Dis 2020:0:1. doi:10.1136/annrheumdis-2020-217651

\section{ORCID iDs}

Philippe Mertz http://orcid.org/0000-0002-9781-7388

Laurent Arnaud http://orcid.org/0000-0002-8077-8394

\section{REFERENCE}

1 Zhu F-X, Huang J-Y, Ye Z, et al. Risk of systemic lupus erythematosus in patients with idiopathic thrombocytopenic purpura: a population-based cohort study. Ann Rheum Dis 2020. doi:10.1136/annrheumdis-2020-217013. [Epub ahead of print: 02 Apr 2020]. 